\title{
Can exercise increase fitness and reduce weight in patients with schizophrenia and depression?
}

\author{
${ }^{1}$ Mental Health Centre Copenhagen, Faculty of Health Sciences, University of Copenhagen, Copenhagen, Denmark \\ ${ }^{2}$ Department of Endocrinology, Herlev University Hospital, Copenhagen, Denmark \\ ${ }^{3}$ Research Unit Department P, Aarhus University Hospital, Risskov, Denmark \\ ${ }^{4}$ Research Center for Health Promotion, University of Roskilde, Roskilde, Denmark
}

Jesper Krogh ${ }^{1,2}$, Helene Speyer ${ }^{1}$, Hans Christian Brix Nørgaard ${ }^{3}$, Ane Moltke ${ }^{1,4}$ and Merete Nordentoft ${ }^{1}$ *

Edited by:

Egil Wilhelm Martinsen, University of Oslo, Norway

Reviewed by:

Ahmed A. Moustafa, University of

Western Sydney, Australia

Jan Ivar Røssberg, University of Oslo,

Norway

*Correspondence:

Merete Nordentoft, Bispebjerg Bakke

23, Copenhagen, Denmark

e-mail:mn@dadlnet.dk
Background: Psychiatric patients have a reduced life expectancy of 15-20 years compared with the general population. Most years of lost life are due to the excess mortality from somatic diseases. Sedentary lifestyle and medication is partly responsible for the high frequency of metabolic syndrome in this patient group and low levels of physical activity is associated with increased risk of cardiovascular disease, diabetes, and all-cause mortality. This study aimed to review trials allocating patients with either schizophrenia or depression to exercise interventions for effect on cardiovascular fitness, strength, and weight.

Methods: We searched PubMed, Embase, and PsycINFO including randomized clinical trial allocating patients with either schizophrenia or depression to isolated exercise interventions.

Results: We identified five trials including patients with schizophrenia $(n=94)$ and found little evidence that exercise could increase cardiovascular fitness or decrease weight. Nine exercise trials for patients with depression $(n=892)$ were identified increasing cardiovascular fitness by $11-30 \%$ and strength by $33-37 \%$. No evidence in favor of exercise for weight reduction was found.

Conclusion: Based on the current evidence isolated exercise interventions are unlikely to improve cardiovascular fitness or induce weight loss in patients with schizophrenia. In patients with depression, exercise interventions are likely to induce clinically relevant short term effects, however, due to lack of reporting, little is known about the effect on weight reduction and cardiovascular fitness. Future exercise trials regarding patients with mental illness should preferably measure changes in cardiovascular strength, repetition maximum, and anthropometric outcomes. Ideally, participants should be assessed beyond the intervention to identify long lasting effects.

\section{Keywords: exercise therapy, schizophrenia, depression, randomised controlled trials, weight loss}

\section{INTRODUCTION}

There is a known increased morbidity and mortality due to illnesses among people with mental disorders. A large Nordic study has recently shown that psychiatric patients have a reduced life expectancy of 15-20 years compared to the general population (1). This excess mortality is to some extent explained by suicide and accidents, but most of lost year of life is due to excess mortality from somatic disease (2). Detailed analysis of mortality from specific causes of death shows that this excess mortality is caused by virtually any physical illness (3).

A study of patients treated with antipsychotic medication in outpatients' services in Copenhagen has shown that the prevalence of metabolic syndrome is twice as high in these patients compared with the general population (4). The metabolic syndrome is a cluster of symptoms related to increased risk of cardiovascular events, type II diabetes, and all-cause mortality. The definition of metabolic syndrome varies, but most includes central obesity, raised blood pressure, high fasting glucose levels, and dyslipidemia (raised triglycerides and lowered high-density lipoproteins) (5). The high prevalence of metabolic syndrome among mentally ill is presumably partly due to weight gain and impaired glucose tolerance, which can be side effects of antipsychotic medication (6). Another reason for the high morbidity and mortality may be the lacking treatment of physical illnesses (7). However, there is also reason to believe that lifestyle factors such as smoking, diet, and exercise habits play a role in the excess mortality, morbidity, and high rates of illnesses. Sedentary lifestyle and poor diet is also more frequent than in the general population $(8,9)$. Low levels of physical activity are associated with increased risk of cardiovascular disease, diabetes, and all-cause mortality $(10,11)$. However, adherence to behavioral interventions in both the general population as well as in patients with mental illness is a major issue (12). The excess morbidity in patients with severe mental illness can be attributed to unhealthy lifestyle, medication, and that patients with 
mental illness do not receive same treatment for physical illnesses as mentally healthy patients. In theory, these are all modifiable factors.

With our current knowledge, there is no reason to believe that the physiological benefit of exercise should be different in mentally ill compared to healthy subjects. However, psychiatric symptoms (e.g., anxiety and lack of energy), medication adverse events (e.g., weight gain and sedation), and factors such as social isolation and difficulties in planning, are issues for many patients with either depression or schizophrenia. Due to these challenges, results from lifestyle interventions in the mentally healthy populations cannot be extrapolated to mentally ill populations.

Exercise, which has a low number of side effects, is affordable for most health care systems and is increasingly an objective for research in this patient group. Furthermore, isolated exercise interventions are simple to implement, less costly, and demands less education of staff compared to more complex interventions. The aim of this study was to review the literature on the effect of exercise interventions on fitness variables such as maximal oxygen uptake and strength. Secondly the aim was to assess the effect of exercise interventions on weight and body mass index (BMI). Also, adherence to exercise interventions will be reviewed.

\section{METHODS}

This study was as a systematic review for the primary aims. We included randomized clinical trials allocating patients diagnosed with schizophrenia, bipolar disorder, or depression according to a diagnostic system (i.e., DSM or ICD) to an exercise intervention or a control group/treatment as usual or to an exercise intervention as add-on treatment. The trials had to report outcomes on change in maximal oxygen uptake, repetition maximum or similar in order to be included. We also searched references in relevant papers for additional trials. Secondly, we included studies aiming to identify exercise participation.

\section{SEARCH STRATEGY}

We searched PubMed, Embase, and PsycINFO using the following text word terms: (mental disorders) AND (health promotion OR exercise physical OR physical therapy OR physical activity OR sports OR "life style intervention" OR life style OR food intake OR diet OR dietary OR nutrition OR nutritive OR nutrition therapy OR cognitive therapy OR behavioral therapy) AND (bipolar disorder OR schizophrenia OR psychoses OR depression OR depressive disorder OR "severe mental disorder") AND (physical fitness OR physical health OR metabolic syndrome OR cardiometabolic OR cardiovascular OR BMI OR body mass index OR body fat OR weight loss OR weight maintenance OR waist to hip ratio OR "study outcome" OR "study intervention"). The main search was conducted in the summer of 2012 and a follow-up search was conducted in March 2014 in PubMed.

\section{DATA EXTRACTION}

Data of participants' baseline characteristics, type of intervention, attendance, and effect on aerobic fitness or strength, and metabolic variables. We expected high heterogeneity of trial interventions, in reporting of effects, and chosen effect estimates and a priori abstained from performing a meta-analysis.

\section{RESULTS}

The updated search in March 2014 resulted in 5742 hits. Five (13-17) trials reporting the effect of exercise interventions for schizophrenia fulfilled the inclusion criteria and were included. Nine trials (18-26) reporting the effect of exercise in patients with depression fulfilled the inclusion criteria and were included. No trials including patients with bipolar disorder fulfilled the inclusion criteria.

\section{THE EFFECT OF EXERCISE ON FITNESS OR STRENGTH IN PATIENTS WITH SCHIZOPHRENIA}

Five trials allocating a total of 141 patients to an exercise intervention or a control group reported the effect on fitness. A summary of these trials can be seen in Table 1. Four studies used aerobic exercise (15-17) and one was a mixed intervention of both strength training as well as aerobic training (14). The vast majority of included participants were outpatients with a mean age between 29 and 52 years. Of the five trials, a recent Dutch study (13) is the most interesting due to its size. In that study, 63 patients were randomly assigned to a training $(n=31)$ or occupational therapy $(n=32)$. The training program consisted mainly of exercises that were intended to increase cardiovascular fitness. There was supervised training twice a week for 6 months. After 6 months, the fitness in the exercise group was significantly higher compared with the control group. This difference was not due to an increase in fitness as a result of training, but a decrease in fitness observed in the control group. However, participants who had an attendance of $<50 \%$ were excluded from this calculation. The authors conclude that the intervention helped maintain an otherwise declining fitness. The remaining four trials included between 12 and 30 participants. None of these trials found a significant effect of exercise on fitness or strength. It should be noted, however, that all four trials reported a non-significant increase in aerobic fitness.

\section{THE EFFECT OF EXERCISE ON BODY WEIGHT IN PATIENTS WITH SCHIZOPHRENIA}

As illustrated in Table 1, four of five trials did not find that exercise reduced weight or BMI. However, one study with soccer intervention found a significant reduction of $4.6 \%$ in weight and BMI (15) and another trial found a 3.7\% decrease in body fat (17).

\section{PARTICIPATION IN EXERCISE INTERVENTIONS IN PATIENTS WITH SCHIZOPHRENIA}

Four of five trials report on attendance. In the Dutch study (13), only participants attending more than $50 \%$ of sessions are included in the assessment. In this "completers" group, the average attendance is 1.5 session/week. In Battaglia et al. (15) using soccer, training $83 \%$ participated in more than $80 \%$ of the 24 offered sessions. In the remaining trials, the mean participation ranged between 1.4 and 2.6 session/week. In the trial by Marzolini et al. (14), they registered barriers for two attendances based on participants' feed-back and found the top four reasons to be unknown (47\%), medical issues including hospitalization $(27 \%)$, supervised trip or family visit $(8 \%)$, and medical appointment (4\%). 
Table 1 | Randomized clinical trials investigating the effect of exercise interventions in patients with schizophrenia.

\begin{tabular}{|c|c|c|c|c|c|c|c|}
\hline Trial & Participants & $\begin{array}{l}\text { Number } \\
\text { participants } \\
\text { randomized }\end{array}$ & $\begin{array}{l}\text { Number of } \\
\text { participants in } \\
\text { included in } \\
\text { final analysis }\end{array}$ & Intervention & Attendance & Results fitness $^{a}$ & Results weight ${ }^{a}$ \\
\hline $\begin{array}{l}\text { Scheewe } \\
\text { et al. (13) }\end{array}$ & $\begin{array}{l}\text { Outpatients } \\
\text { Mean age: } 29.7 \\
\text { Female: } 17 / 63 \\
(27 \%)\end{array}$ & $\begin{array}{l}E=31 \\
C=32\end{array}$ & $\begin{array}{l}E=17 \\
C=16\end{array}$ & $\begin{array}{l}\text { Supervised aerobic } \\
\text { exercise. Two } \\
\text { sessions/week for } \\
6 \text { months }\end{array}$ & $\begin{array}{l}\text { E: } 20 / 31 \text { participants } \\
\text { attended }>50 \% \text {. } \\
\text { Mean attendance } \\
\text { was for these } 20 \\
\text { participants was } \\
1.5 \text { session/week }\end{array}$ & $\begin{array}{l}\text { Change in aerobic } \\
\text { fitness was } \\
\text { significantly higher in } \\
\text { E-group }\end{array}$ & $\begin{array}{l}\text { No significant } \\
\text { effect on BMI or } \\
\text { waist } \\
\text { circumference }\end{array}$ \\
\hline $\begin{array}{l}\text { Battaglia } \\
\text { et al. (15) }\end{array}$ & $\begin{array}{l}\text { Outpatients } \\
\text { Mean age: } 35.5 \\
\text { Female: } 0 / 23 \\
(0.0 \%)\end{array}$ & $\begin{array}{l}E=12 \\
C=11\end{array}$ & $\begin{array}{l}E=10 \\
C=8\end{array}$ & $\begin{array}{l}\text { Supervised soccer } \\
\text { training. Two } \\
\text { sessions/week for } \\
3 \text { months }\end{array}$ & $\begin{array}{l}\text { Exercise group: } \\
83 \% \text { participated in } \\
>80 \% \text { of sessions }\end{array}$ & $\begin{array}{l}\text { No significant effect } \\
\text { on } 30 \mathrm{~m} \text { sprint } \\
\text { performance }\end{array}$ & $\begin{array}{l}\text { Significant } \\
\text { reduction in } \\
\text { weight and } \mathrm{BMI} \\
\text { of } 4.6 \% \text { E-group }\end{array}$ \\
\hline $\begin{array}{l}\text { Marzolini } \\
\text { et al. (14) }\end{array}$ & $\begin{array}{l}\text { Outpatients } \\
\text { Mean age: } 44.9 \\
\text { Female: } 7 / 15 \\
(47 \%)\end{array}$ & $\begin{array}{l}E=7 \\
C=6\end{array}$ & $\begin{array}{l}E=7 \\
C=6\end{array}$ & $\begin{array}{l}\text { Supervised mixed } \\
\text { aerobic and } \\
\text { strength training. } \\
\text { Two sessions/week } \\
\text { for } 3 \text { months }\end{array}$ & $\begin{array}{l}\text { Exercise group: } \\
\text { mean attendance } \\
\text { was } \\
1.44 \text { sessions/week }\end{array}$ & $\begin{array}{l}\text { E-group increased } \\
6 \text { min walking test by } \\
28 \mathrm{~m} \text { and a } 28 \% \\
\text { increase in strength }\end{array}$ & $\begin{array}{l}\text { No significant } \\
\text { effect on weight } \\
\text { or waist } \\
\text { circumference }\end{array}$ \\
\hline $\begin{array}{l}\text { Beebe } \\
\text { et al. (17) }\end{array}$ & $\begin{array}{l}\text { Outpatients } \\
\text { Mean age }^{\text {b. }} 52 \\
\text { Female }^{\text {b: }: 2 / 10} \\
(20 \%)\end{array}$ & $\begin{array}{l}E=6 \\
C=6\end{array}$ & $\begin{array}{l}E=4 \\
C=6\end{array}$ & $\begin{array}{l}\text { Supervised aerobic } \\
\text { exercise. Three } \\
\text { sessions/week for } \\
4 \text { months }\end{array}$ & Not reported & $\begin{array}{l}\text { E-group could walk } \\
29 \mathrm{~m} \text { longer in a 6-min } \\
\text { test. Not significant }\end{array}$ & $\begin{array}{l}\text { No significant } \\
\text { effect on BMI. A } \\
\text { significant } \\
\text { decrease in body } \\
\text { fat of } 3.7 \% \text { in } \\
\text { E-group }\end{array}$ \\
\hline $\begin{array}{l}\text { Skrinar } \\
\text { et al. (16) }\end{array}$ & $\begin{array}{l}\text { Outpatients and } \\
\text { in-patients } \\
\text { Mean age: } 38 \\
\text { Female: } 20 / 30 \\
(66.7 \%)\end{array}$ & $\begin{array}{l}E=15 \\
C=15\end{array}$ & $\begin{array}{l}E=9 \\
C=11\end{array}$ & $\begin{array}{l}\text { Supervised aerobic } \\
\text { exercise. Four } \\
\text { sessions/week for } \\
3 \text { months }\end{array}$ & $\begin{array}{l}\text { Exercise group: } \\
\text { mean attendance } \\
\text { was } \\
2.6 \text { sessions/week }\end{array}$ & $\begin{array}{l}\text { E-group increased } \\
\text { exercise performance } \\
\text { from } 153 \text { to } 161 \mathrm{~W} \text { on } \\
\text { bicycle test. Not } \\
\text { significant }\end{array}$ & $\begin{array}{l}\text { No significant } \\
\text { effect on weight, } \\
\text { BMI, or \% body } \\
\text { fat }\end{array}$ \\
\hline
\end{tabular}

E, exercise group; $C$, control group.

a Significant' refers to between-group differences.

${ }^{b}$ Age and gender is only reported for completers.

\section{THE EFFECT OF EXERCISE ON FITNESS OR STRENGTH IN PATIENTS WITH DEPRESSION}

As reported in Table 2, nine trials reporting on the effect of exercise on fitness or strength was identified. These 9 trials included a total of 950 patients. Six trials used aerobic interventions (19-22) and two trials investigated the effect of strength training $(18,23)$. In one trial (27), the participants were encouraged to engage in preferred exercise activities offered in the community. The range of mean age was between 36 and 71 years of age. Two of nine trials investigated the effect of exercise in inpatients $(24,26)$.

Five of six trials offering aerobic exercise found a positive and significant effect on fitness levels in the range of $11-30 \%$ in maximal oxygen uptake. The two trials investigating the effect of strength training both found an increase in strength between 33 and $37 \%$.

The largest study to date is the British TREAD study (25) using motion advisors trying to facilitate more physical activity in daily life in patients. Patients could choose how they wanted to increase their physical activity, and were supported in their attempt to this lifestyle change through meetings or telephone conversations with their exercise counselor. In Great Britain, authorities recommend that adults are active approximately $150 \mathrm{~min} /$ week, and the TREAD study could, on the basis of questionnaires, assess the number of participants, respectively exercise and the control group that met these requirements after intervention. It turned out that the chance of a participant in the exercise group met the official recommendation for physical activity after the intervention was twice higher (OR 2.27, 95\% CI 1.32-3.89, $p=0.003$ ) compared to a participant from the control group.

\section{THE EFFECT OF EXERCISE ON BODY WEIGHT IN PATIENTS WITH DEPRESSION}

Only one trial reports the effect of exercise on body weight (19) and it found no effect on weight or BMI. However, the 
Table 2 | Randomized clinical trials reporting effect of exercise interventions on physical fitness or strength in patients with depression.

\begin{tabular}{|c|c|c|c|c|c|c|c|}
\hline Trial & Participants & $\begin{array}{l}\text { Number of } \\
\text { participants } \\
\text { randomized }\end{array}$ & $\begin{array}{l}\text { Number of } \\
\text { participants } \\
\text { included in } \\
\text { final analysis }\end{array}$ & Intervention & Attendance & Results fitness & Results weight \\
\hline $\begin{array}{l}\text { Krogh et al. } \\
\text { (19) }\end{array}$ & $\begin{array}{l}\text { Outpatients } \\
\text { Mean age: } 41.6 \\
\text { Female: } 77 / 115 \\
(70 \%)\end{array}$ & $\begin{array}{l}E=56 \\
C=59\end{array}$ & $\begin{array}{l}E=56 \\
C=59\end{array}$ & $\begin{array}{l}\text { Supervised } \\
\text { aerobic exercise. } \\
\text { Three } \\
\text { sessions/week } \\
\text { for } 3 \text { months }\end{array}$ & $\begin{array}{l}\text { Average } \\
\text { number of } \\
\text { attended } \\
\text { sessions } \\
1.1 / \text { week }\end{array}$ & $\begin{array}{l}\text { Significant increase in } \\
\text { maximal oxygen uptake by } \\
13 \% \text { in E-group compared } \\
\text { to C-group }\end{array}$ & $\begin{array}{l}\text { No effect on weight } \\
\text { or BMI. Significant } \\
\text { reduction in waist } \\
\text { circumference }-2 \mathrm{~cm}\end{array}$ \\
\hline $\begin{array}{l}\text { Chalder } \\
\text { et al. ( } 25, \\
27)\end{array}$ & $\begin{array}{l}\text { Outpatients } \\
\text { Mean age: } 39.9 \\
\text { Female: } 122 / 361 \\
(33.8 \%)\end{array}$ & $\begin{array}{l}E=182 \\
C=179\end{array}$ & $\begin{array}{l}E=151 \\
C=165\end{array}$ & $\begin{array}{l}\text { Exercise coaching } \\
\text { face to face and } \\
\text { by telephone } \\
\text { during an } \\
\text { 8-months period }\end{array}$ & Not reported & $\begin{array}{l}\text { Significant effect of } \\
\text { intervention: in E-group } \\
63 \% \text { of participants were } \\
\text { physically active } \\
>150 \mathrm{~min} / \text { week compared } \\
\text { to } 49 \% \text { in C-Group }\end{array}$ & Not reported \\
\hline $\begin{array}{l}\text { Knubben } \\
\text { et al. (24) }\end{array}$ & $\begin{array}{l}\text { Inpatients } \\
\text { Mean age: } 49.5 \\
\text { Female: } 21 / 38 \\
(55.3 \%)\end{array}$ & $\begin{array}{l}E=20 \\
C=18\end{array}$ & $\begin{array}{l}E=20 \\
C=18\end{array}$ & $\begin{array}{l}\text { Daily supervised } \\
\text { aerobic exercise } \\
\text { sessions for } \\
10 \text { days }\end{array}$ & Not reported & $\begin{array}{l}\text { No difference in maximal } \\
\text { oxygen uptake }\end{array}$ & Not reported \\
\hline $\begin{array}{l}\text { Blumenthal } \\
\text { et al. (22) }\end{array}$ & $\begin{array}{l}\text { Outpatients } \\
\text { Mean age: } 52.0 \\
\text { Female: } 23 / 100 \\
(23 \%)\end{array}$ & $\begin{array}{l}E=51 \\
C=49\end{array}$ & $\begin{array}{l}E=51 \\
C=49\end{array}$ & $\begin{array}{l}\text { Supervised } \\
\text { aerobic exercise. } \\
\text { Three } \\
\text { sessions/week } \\
\text { for } 4 \text { months }\end{array}$ & $\begin{array}{l}\text { Median } \\
\text { number of } \\
\text { attended } \\
\text { sessions: } \\
\text { 2.3/week }\end{array}$ & $\begin{array}{l}\text { Significant increase in } \\
\text { maximal oxygen uptake in } \\
\text { E-group compared to } \\
\text { C-group } 9.1 \%\end{array}$ & Not reported \\
\hline $\begin{array}{l}\text { Blumenthal } \\
\text { et al. (21) }\end{array}$ & $\begin{array}{l}\text { Outpatients } \\
\text { Mean age: } 57.0 \\
\text { Female: } 74 / 103 \\
(71.8 \%)\end{array}$ & $\begin{array}{l}E=55 \\
C=48\end{array}$ & $\begin{array}{l}E=55 \\
C=48\end{array}$ & $\begin{array}{l}\text { Supervised } \\
\text { aerobic exercise. } \\
\text { Three } \\
\text { sessions/week } \\
\text { for } 4 \text { months }\end{array}$ & $\begin{array}{l}\text { Average } \\
\text { number of } \\
\text { attended } \\
\text { sessions: } \\
2.7 / \text { week }\end{array}$ & $\begin{array}{l}\text { Significant increase of } \\
\text { maximal oxygen uptake by } \\
11 \% \text { in E-group }\end{array}$ & Not reported \\
\hline $\begin{array}{l}\text { Singh et al. } \\
\text { (18) }\end{array}$ & $\begin{array}{l}\text { Outpatients } \\
\text { Mean age: } 71.3 \\
\text { Female: } 20 / 32 \\
(71.8)\end{array}$ & $\begin{array}{l}E=17 \\
C=17\end{array}$ & $\begin{array}{l}E=15 \\
C=15\end{array}$ & $\begin{array}{l}\text { Supervised } \\
\text { strength training. } \\
\text { Three } \\
\text { sessions/week } \\
\text { for } 2.5 \text { months }\end{array}$ & $\begin{array}{l}\text { Median } \\
\text { number of } \\
\text { attended } \\
\text { sessions: } \\
\text { 3.0/week }\end{array}$ & $\begin{array}{l}\text { Significant increase in } \\
\text { muscle strength by } 33 \% \text { in } \\
\text { E-group }\end{array}$ & Not reported \\
\hline $\begin{array}{l}\text { Martinsen } \\
\text { et al. (26) }\end{array}$ & $\begin{array}{l}\text { Inpatients } \\
\text { Mean age: } 40.0 \\
\text { Female: not } \\
\text { reported }\end{array}$ & $\begin{array}{l}E=28 \\
C=21\end{array}$ & $\begin{array}{l}E=24 \\
C=19\end{array}$ & $\begin{array}{l}\text { Supervised } \\
\text { aerobic exercise. } \\
\text { Three sessions/ } \\
\text { week for } 9 \text { weeks }\end{array}$ & Not reported & $\begin{array}{l}\text { Significant increase in } \\
\text { maximal oxygen uptake by } \\
30 \% \text { in the E-group }\end{array}$ & Not reported \\
\hline
\end{tabular}

E, exercise group; $C$, control group.

Authors estimate based on graph in original report. 
intervention group reduced their waist circumference with $2 \mathrm{~cm}$ post-intervention.

\section{PARTICIPATION IN EXERCISE TRIALS WITH DEPRESSED PATIENTS}

Six trials report on adherence (18-23). Mean attendance in aerobic trials ranged from 1.1 to 2.7 sessions/week. The two strength training trials reported a median attendance of 3 sessions/week. None of the trials report on reasons for lack of attendance.

\section{DISCUSSION}

Trials examining the effect of exercise in patients with schizophrenia are small in number and size. There is little evidence that exercise interventions will increase cardiovascular fitness or lead to decreased weight in this patient group. There is convincing evidence that depressed outpatients participating in strength or aerobic training will improve their fitness in terms of maximal oxygen uptake or repetition maximum. However, there is little evidence that exercise interventions in patients will depression will decrease their weight.

Four of five trials assessing exercise in patients with schizophrenia found a positive effect on fitness levels and lack of significance is likely to be a type II error due to the small sample sizes. However, in the larger study by Scheewe et al. (13), the significant differences in aerobic fitness were due to a decrease in fitness in the control group and not an increase in the intervention group. In six trials including patients with depression to aerobic exercise, five had a significant increase maximal oxygen uptake. The trials that did not improve aerobic fitness was a 10-day intervention of inpatients by Knubben et al. (24), which is probably too short an intervention to gain physiological improvement. In a Finnish study of 1639 men (42-60 years) without a history of type II diabetes or atherosclerotic cardiovascular maximal oxygen uptake was associated with $16 \%$ reduction of all-cause mortality per one increment in MET $(3.5 \mathrm{ml}$ oxygen $/ \mathrm{min} / \mathrm{kg}$ ) during an average follow-up of 16 years (28). In the DEMO-I trial, the aerobic exercise groups increased their aerobic capacity equivalent to an increase of 0.83 METs and in the DEMO-II trial, the increase was equivalent to 0.97 METs $(19,20)$. This suggests that the increase in cardiovascular fitness observed in exercise trials of depressed patients is clinically relevant. On the other hand, no data exists on maximal oxygen uptake beyond the intervention and therefore the current evidence does not allow conclusions or speculations whether the observed increases in cardiovascular fitness is transformed to any benefit for the patients on hard endpoints.

Patients with schizophrenia are unlikely to decrease weight in response to exercise interventions. For patients with depression only one trial reported on weight and found no weight reducing effect of exercise participation (19). However, in that trial a reduction of waist circumference was found in the intervention group reflecting a potential redistribution of weight from abdominal fat to muscle. A recent meta-analysis confirms the effect of both moderate to high intensity aerobic training and strength training for reduction of visceral fat (29). Isolated aerobic exercise as an intervention for weight loss in overweight or obese populations has in meta-analysis been found to reduce weight by $1.6 \mathrm{~kg}$, waist circumference of $2.1 \mathrm{~cm}$, diastolic blood pressure with $1.8 \mathrm{mmHg}$, and total cholesterol with $1.54 \mathrm{mg} / \mathrm{dl}$ for 6 month programs (30). These results suggest that even in mentally healthy populations an isolated aerobic intervention is not likely to induce dramatic changes in weight or waist circumference.

These findings open a discussion whether multiple interventions should be employed, i.e., combined exercise and diet interventions. In mentally healthy populations, the combination of exercise and diet interventions for weight loss has been shown to be superior to exercise alone (31). A trial of patients with severe mental illness allocated to an intervention containing both of advice on diet as well as exercise obtained a weight loss of $3.2 \mathrm{~kg}$ after 18 months duration (32). A meta-analysis of 17 nonpharmacological interventions in patients with severe mental illness supports these findings with an overall weight reduction of $3.12 \mathrm{~kg}$ (33). However, only five trials reported the effect beyond the intervention with conflicting results on weight and BMI (33). For schizophrenia, only a few and mainly very small trials fulfilled the inclusion criteria for this review. The main reasons for exclusion of trials were lack of diagnosis (e.g., not specifying diagnostic instrument) and the use of mixed interventions (e.g., exercise and diet versus treatment as usual). The results from this review should be interpreted in that context. Taken together, isolated exercise interventions in patients with schizophrenia or depression are unlikely to induce clinically relevant weight loss. On the other hand, there is evidence in favor of mixed interventions for weight loss.

Regarding adherence to exercise intervention in patients with schizophrenia, there was a trend for high attendance in small trials whereas larger trials had lower attendance. Previous studies have tried to identify barriers to physical activity and limited experience of physical, activity engagement, impact of the illness and effects of medication, and anxiety is mentioned by one study (34) and partially confirmed in a smaller study (35). The authors have recently investigated predictors of adherence in exercise trials including patients with depression and found that age and satisfaction with the intervention was associated with higher adherence (36). The age aspect could explain some of the variation observed in attendance in trials with depressed patients. Unfortunately, the majority of included trials do not mention considerations regarding attendance.

Based on the current evidence isolated exercise interventions are unlikely to improve cardiovascular fitness or induce weight loss in patients with schizophrenia, but there are few studies and thus a rather small evidence base. In patients with depression, exercise interventions are likely to induce clinically relevant short term effects, however, due to lack of reporting, little is known about the weight reduction. Future exercise trials in patients with mental illness should preferably measure changes in cardiovascular strength, repetition maximum, and anthropometric outcomes. Ideally, participants should be assessed beyond the intervention to obtain knowledge on lasting effects.

\section{REFERENCES}

1. Nordentoft M, Wahlbeck K, Hällgren J, Westman J, Osby U, Alinaghizadeh H, et al. Excess mortality, causes of death and life expectancy in 270,770 patients with recent onset of mental disorders in Denmark, Finland and Sweden. PLoS One (2013) 8:e55176. doi:10.1371/journal.pone.0055176

2. Laursen TM. Life expectancy among persons with schizophrenia or bipolar affective disorder. Schizophr Res (2011) 131:101-4. doi:10.1016/j.schres.2011.06.008

3. Laursen T, Munk-Olsen T, Nordentoft M, Mortensen P. Increased mortality among patients admitted with major psychiatric disorders: a register-based study 
comparing mortality in unipolar depressive disorder, bipolar affective disorder, schizoaffective disorder, and schizophrenia. J Clin Psychiatry (2007) 68:899-907. doi:10.4088/JCP.v68n1106

4. Krane-Gartiser K, Breum L, Glümer C, Linneberg A, Madsen M, Køster A, et al. Prevalence of the metabolic syndrome in Danish psychiatric outpatients treated with antipsychotics. Nord J Psychiatry (2011) 65:345-52. doi:10.3109/08039488. 2011.565799

5. Alberti KG, Eckel RH, Grundy SM, Zimmet PZ, Cleeman JI, Donato KA, et al. Harmonizing the metabolic syndrome: a joint interim statement of the International Diabetes Federation Task Force on Epidemiology and Prevention; National Heart, Lung, and Blood Institute; American Heart Association; World Heart Federation; International Atherosclerosis Society; and International Association for the Study of Obesity. Circulation (2009) 120:1640-5. doi:10.1161/CIRCULATIONAHA.109.192644

6. Daumit GL, Goff DC, Meyer JM, Davis VG, Nasrallah HA, McEvoy JP, et al. Antipsychotic effects on estimated 10-year coronary heart disease risk in the CATIE schizophrenia study. Schizophr Res (2008) 105:175-87. doi:10.1016/j. schres.2008.07.006

7. Laursen TM, Munk-Olsen T, Agerbo E, Gasse C, Mortensen PB. Somatic hospital contacts, invasive cardiac procedures, and mortality from heart disease in patients with severe mental disorder. Arch Gen Psychiatry (2009) 66:713-20. doi:10.1001/archgenpsychiatry.2009.61

8. Daumit GL, Goldberg RW, Anthony C, Dickerson F, Brown CH, Kreyenbuhl J, et al. Physical activity patterns in adults with severe mental illness. J Nerv Ment Dis (2005) 193:641-6. doi:10.1097/01.nmd.0000180737.85895.60

9. Strassnig M, Singh BJ, Ganguli R. Dietary fatty acid and antioxidant intake in community-dwelling patients suffering from schizophrenia. Schizophr Res (2005) 76:343-51. doi:10.1016/j.schres.2005.03.002

10. Kodama S, Saito K, Tanaka S, Maki M, Yachi Y, Asumi M, et al. Cardiorespiratory fitness as a quantitative predictor of all-cause mortality and cardiovascular events in healthy men and women: a meta-analysis. JAMA (2009) 301:2024-35. doi:10.1001/jama.2009.681

11. Myers J, Prakash M, Froelicher V, Do D, Partington S, Atwood JE. Exercise capacity and mortality among men referred for exercise testing. N Engl J Med (2002) 346:793-801. doi:10.1056/NEJMoa011858

12. Davis MJ, Addis ME. Predictors of attrition from behavioral medicine treatments. Ann Behav Med (1999) 21:339-49. doi:10.1007/BF02895967

13. Scheewe TW, van Haren NE, Sarkisyan G, Schnack HG, Brouwer RM, de Glint $M$, et al. Exercise therapy, cardiorespiratory fitness and their effect on brain volumes: a randomised controlled trial in patients with schizophrenia and healthy controls. Eur Neuropsychopharmacol (2013) 23:675-85. doi:10.1016/j. euroneuro.2012.08.008

14. Marzolini S, Jensen B, Melville P. Feasibility and effects of a group-based resistance and aerobic exercise program for individuals with severe schizophrenia: a multidisciplinary approach. Ment Health Phys Act (2009) 2:29-36. doi:10.1016/j.mhpa.2008.11.001

15. Battaglia G, Alesi M, Inguglia M, Roccella M, Caramazza G, Bellafiore M, et al. Soccer practice as an add-on treatment in the management of individuals with a diagnosis of schizophrenia. Neuropsychiatr Dis Treat (2013) 9:595-603. doi:10.2147/NDT.S44066

16. Skrinar GS, Huxley NA, Hutchinson DS, Menninger E, Glew P. The role of a fitness intervention on people with serious psychiatric disabilities. Psychiatr Rehabil J (2005) 29:122-7. doi:10.2975/29.2005.122.127

17. Beebe L, Tian L, Morris N, Goodwin A, Allen S, Kuldau J. Effects of exercise on mental and physical health parameters of persons with schizophrenia. Issues Ment Health Nurs (2005) 26:661-76. doi:10.1080/01612840590959551

18. Singh N, Clements K, Fiatarone M. A randomized controlled trial of progressive resistance training in depressed elders. J Gerontol (1997) 52:M27-35. doi:10.1093/gerona/52A.1.M27

19. Krogh J, Videbech P, Thomsen C, Gluud C, Nordentoft M. DEMO-II trial. Aerobic exercise versus stretching exercise in patients with major depression - a randomised clinical trial. PLoS One (2012) 7(10):e48316. doi:10.1371/journal. pone. 0048316

20. Krogh J, Saltin B, Gluud C, Nordentroft M. The DEMO trial: a randomized, parallel-group, observer-blinded clinical trial of strength versus aerobic versus relaxation training for patients with mild to moderate depression. J Clin Psychiatry (2009) 70(6):790-800. doi:10.4088/JCP.08m04241

21. Blumenthal J, Babyak MA, Moore KA, Craighead WE, Herman S, Khatri P. Effects of exercise training on older patients with major depression. Arch Intern Med (1999) 159:2349-56. doi:10.1001/archinte.159.19.2349
22. Blumenthal J, Babyak M, Doraiswamy P, Watkins L, Hoffman B, Barbour K, et al. Exercise and pharmacotherapy in the treatment of major depressive disorder. Psychosom Med (2007) 69:587-96. doi:10.1097/PSY.0b013e318148c19a

23. Singh N, Stavrinos T, Scarbek Y, Galambos G, Liber C, Singh M. A randomized controlled trial of high versus low intensity weight training versus general practitioner care for clinical depression in older adults. J Gerontol (2005) 60:768-76. doi:10.1093/gerona/60.6.768

24. Knubben K, Reischies FM, Adli M, Schlattmann P, Bauer M, Dimeo F. A randomised, controlled study on the effects of a short-term endurance training programme in patients with major depression. Br J Sports Med (2007) 41:29-33. doi:10.1136/bjsm.2006.030130

25. Chalder M, Wiles NJ, Campbell J, Hollinghurst SP, Haase AM, Taylor AH, et al. Facilitated physical activity as a treatment for depressed adults: randomised controlled trial. BMJ (2012) 344:e2758. doi:10.1136/bmj.e2758

26. Martinsen EW, Medhus A, Sandvik L. Effects of aerobic exercise on depression: a controlled study. BMJ (1985) 291:109. doi:10.1136/bmj.291.6488.109

27. Chalder M, Wiles NJ, Campbell J, Hollinghurst SP, Searle A, Haase AM, et al. A pragmatic randomised controlled trial to evaluate the cost-effectiveness of a physical activity intervention as a treatment for depression: the treating depression with physical activity (TREAD) trial. Health Technol Assess (2012) 16:1-164, iii-iv. doi:10.3310/hta16100

28. Laukkanen J, Rauramaa R, Salonen JT, Kurl S. The predictive value of cardiorespiratory fitness combined with coronary risk evaluation and the risk of cardiovascular and all-cause death. J Intern Med (2007) 262:263-72. doi:10.1111/j. 1365-2796.2007.01807.x

29. Vissers D, Hens W, Taeymans J, Baeyens J, Poortmans J, Van Gaal L. The effect of exercise on visceral adipose tissue in overweight adults: a systematic review and meta-analysis. PLoS One (2013) 8:e56415. doi:10.1371/journal.pone.0056415

30. Thorogood A, Mottillo S, Shimony A, Filion K, Joseph L, Genest J, et al. Isolated aerobic exercise and weight loss: a systematic review and meta-analysis of randomized controlled trials. Am J Med (2011) 124:747-55. doi:10.1016/j.amjmed. 2011.02.037

31. Shaw K, Gennat H, O'Rourke P, Del MC. Exercise for overweight or obesity. Cochrane Database Syst Rev (2006) 4:CD003817. doi:10.1002/14651858. CD003817.pub3

32. Daumit GL, Dickerson FB, Wang NY, Dalcin A, Jerome GJ, Anderson CA, et al. A behavioral weight-loss intervention in persons with serious mental illness. $N$ Engl J Med (2013) 368:1594-602. doi:10.1056/NEJMoa1214530

33. Caemmerer J, Correll CU, Maayan L. Acute and maintenance effects of nonpharmacologic interventions for antipsychotic associated weight gain and metabolic abnormalities: a meta-analytic comparison of randomized controlled trials. Schizophr Res (2012) 140:159-68. doi:10.1016/j.schres.2012.03.017

34. Johnstone R, Nicol K, Donaghy M, Lawrie S. Barriers to uptake of physical activity in community-based patients with schizophrenia. J Ment Health (2009) 18:523-32. doi:10.3109/09638230903111114

35. McDevitt J, Snyder M, Miller A, Wilbur J. Perceptions of barriers and benefits to physical activity among outpatients in psychiatric rehabilitation. J Nurs Scholarsh (2006) 38:50-5. doi:10.1111/j.1547-5069.2006.00077.x

36. Krogh J, LorentzenA, Subhi Y, Nordentoft M. Predictors of adherence to exercise interventions in patients with clinical depression - a pooled analysis from two clinical trials. Ment Health Phys Act (2014) 7:50-4. doi:10.3310/hta15440

Conflict of Interest Statement: The authors declare that the research was conducted in the absence of any commercial or financial relationships that could be construed as a potential conflict of interest.

Received: 06 May 2014; accepted: 10 July 2014; published online: 28 July 2014. Citation: Krogh J, Speyer H, Nørgaard HCB, Moltke A and Nordentoft M (2014) Can exercise increase fitness and reduce weight in patients with schizophrenia and depression? Front. Psychiatry 5:89. doi: 10.3389/fpsyt.2014.00089

This article was submitted to Schizophrenia, a section of the journal Frontiers in Psychiatry.

Copyright $(9) 2014$ Krogh, Speyer, Nørgaard, Moltke and Nordentoft. This is an openaccess article distributed under the terms of the Creative Commons Attribution License (CC BY). The use, distribution or reproduction in other forums is permitted, provided the original author(s) or licensor are credited and that the original publication in this journal is cited, in accordance with accepted academic practice. No use, distribution or reproduction is permitted which does not comply with these terms. 